\title{
Genetic control of the rate of transmission of rye B chromosomes. IV. Localization of the genes controlling $B$ transmission rate
}

\author{
MARÍA J . PUERTAS*, MÓNICA GONZÁLEZ-SÁNCHEZZ, SILVIA MANZANERO, FÉLIX \\ ROMERA \& M. MAR J IMÉNEZ \\ Departamento de Genética, Facultad de Biología, Universidad Complutense, 28040 Madrid, Spain
}

\begin{abstract}
Crosses between rye plants from selected lines for high and low B chromosome transmission rate were carried out to determine the location of the genes controlling $\mathrm{B}$ transmission rate. Our results show that they are located on the Bs and we hypothesize that such 'genes' are sites for chiasma formation. Our results also suggest that rye B chromosome polymorphism is controlled mainly by the Bs.
\end{abstract}

Keywords: B chromosomes, B transmission, rye, Secale cereale.

\section{Introduction}

Rye B chromosome transmission is non-Mendelian owing to the mechanism of accumulation and to the variable behaviour of the Bs during meiosis and gametogenesis (see Jones \& Puertas, 1993 for a review). The mechanism of accumulation consists of nondisjunction at the first division of the male and female gametophytes and preferential segregation to the nucleus which will form the gametes.

$\mathrm{B}$ transmission rate in $2 \mathrm{~B} \times 0 \mathrm{~B}$ crosses is highly variable (Puertas et al., 1990). In some crosses the Bs tend to be lost showing a mean of less than $1 \mathrm{~B}$ per plant in the progeny, whereas others show B accumulation. In previous papers (Romera et al., 1991; Jiménez et al., 1995) we have shown that rye B transmission rate is genetically controlled. We selected genotypes of high $(\mathrm{H})$ and low $(\mathrm{L})$ mean number of $\mathrm{Bs}$ in the progeny of $2 \mathrm{~B} \times 0 \mathrm{~B}$ crosses. $\mathrm{B}$ loss in the $\mathrm{L}$ line is caused by a high frequency of $\mathrm{B}$ univalents at metaphase I which results in their loss during pollen grain development. The $\mathrm{B}$ accumulation in the $\mathrm{H}$ line results from regular meiotic behaviour followed by nondisjunction at first pollen metaphase (Jiménez et al., 1997).

In the present paper we show the results of crosses designed to determine if the rye $\mathrm{B}$ transmission control genes selected in the $\mathrm{L}$ and $\mathrm{H}$ lines are located on the normal chromosome set (As) or on the Bs. The implications for understanding B polymorphism in natural populations are different in

*Correspondence. E-mail: majetas@eucmax.sim.ucm.es each case. To date, the situation has been seen as a 'coevolutionary race' between the mechanism of accumulation of the Bs and genotypes on the As which may evolve counteracting the accumulation of the Bs (Beukeboom, 1994; Camacho et al., 1996), or looked upon as As and Bs in some species having a host-parasite interaction with coevolutionary forces acting to determine equilibrium frequencies in populations (Jones, 1995).

\section{Materials and methods}

The selection process of the $\mathrm{L}$ and $\mathrm{H}$ lines for the character mean number of Bs per plant in the progeny was described in Romera et al. (1991) and Jiménez et al. (1995). In summary it consisted of selecting plants from $2 \mathrm{~B} \times 0 \mathrm{~B}$ crosses of the Puyo population showing a strong tendency to lose or to accumulate the $\mathrm{Bs}$ in the $\mathrm{L}$ and $\mathrm{H}$ lines, respectively.

In the first selected generation (G1) the Bs were transmitted on the female side (female $2 \mathrm{~B} \times$ male $0 \mathrm{~B}$ crosses); the L line showed strong $\mathrm{B}$ loss (mean number of Bs per plant in the progeny $(\mathrm{mBs})=0.55)$, whereas in the $\mathrm{H}$ line the Bs were strongly accumulated $(\mathrm{mBs}=1.85)$. In the second selected generation the Bs were transmitted by the male (female $0 \mathrm{~B} \times$ male $2 \mathrm{~B}$ crosses); the $\mathrm{L}$ line transmitted the Bs nearly at a Mendelian rate $(\mathrm{mBs}=1.03)$, whereas they were accumulated in the $\mathrm{H}$ line $(\mathrm{mBs}=1.33)$.

The scheme of the crosses studied in the present work (G3) is shown in Fig. 1. 
In plot 1 , both the $2 \mathrm{~B}$ and $\mathrm{OB}$ plants of $\mathrm{G} 3$ came from a female $0 \mathrm{BL} \times$ male $2 \mathrm{BL}$ cross of $\mathrm{G} 2$ showing 0.54 Bs per plant in the progeny; therefore, both the Bs and the As belong to the $\mathrm{L}$ line.

In plot 2 , both the $2 \mathrm{~B}$ and $\mathrm{OB}$ plants of $\mathrm{G} 3$ came from a female $0 \mathrm{BH} \times$ male $2 \mathrm{BH}$ cross of $\mathrm{G} 2$ showing 1.56 Bs per plant in the progeny; therefore, both the $\mathrm{Bs}$ and the As belong to the $\mathrm{H}$ line.

In plot 3 , both the $2 \mathrm{~B}$ and $\mathrm{OB}$ plants of $\mathrm{G} 3$ came from a female $0 \mathrm{BL} \times$ male $2 \mathrm{BH}$ cross of $\mathrm{G} 2$, showing 1.37 Bs per plant in the progeny; therefore, the Bs belong to the $\mathrm{H}$ line, whereas the As are $\mathrm{LH}$ hybrids.

In plot 4 , both the $2 \mathrm{~B}$ and $\mathrm{OB}$ plants of $\mathrm{G} 3$ came from a female $0 \mathrm{BH} \times$ male $2 \mathrm{BL}$ cross of $\mathrm{G} 2$, showing 0.82 Bs per plant in the progeny; therefore, the Bs belong to the L line, whereas the As are HL hybrids.

In every plot 12 plants were sown, six $0 \mathrm{~B}$ to act as pollinators and six $2 \mathrm{~B}$ were emasculated to be used as females, with the exception of plot two where only five $2 \mathrm{~B}$ plants were available. The offspring were collected from the emasculated plants of these female $2 \mathrm{~B} \times$ male $0 \mathrm{~B}$ crosses.
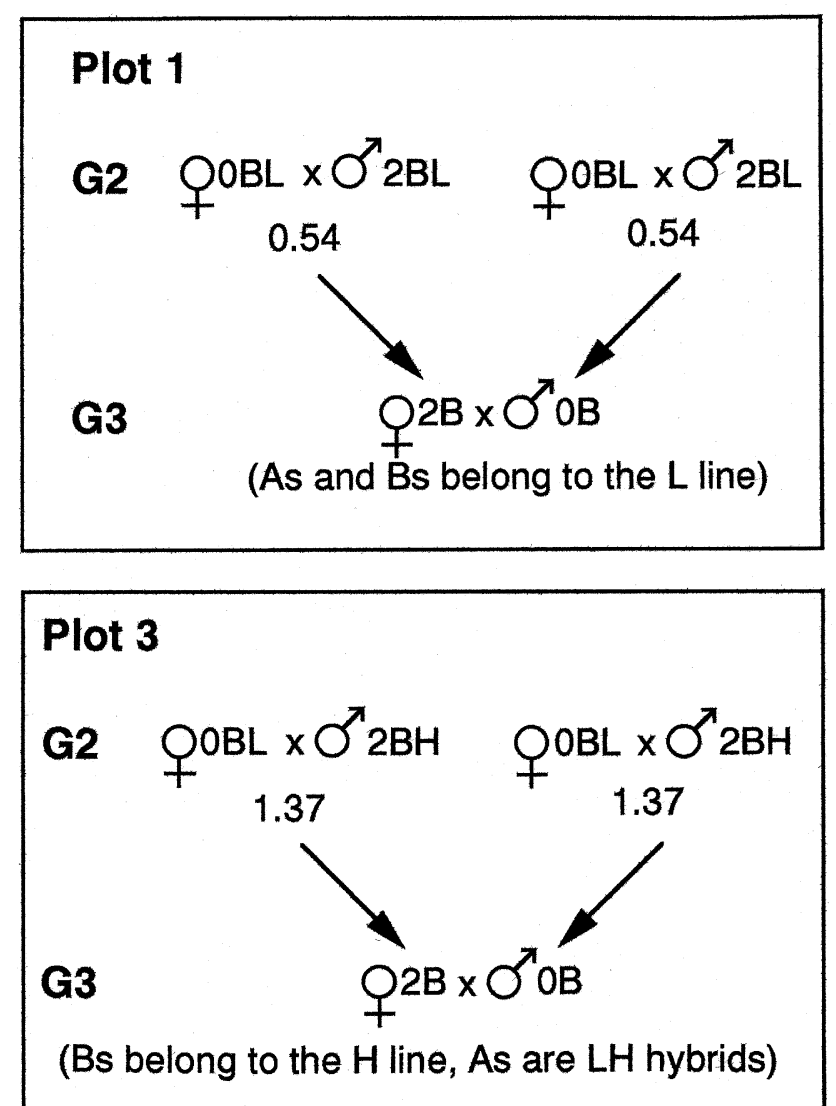

Fig. 1 Scheme of the Secale cereale crosses.
Seedlings were scored for B chromosome number in root tips following fixation in 1:3 acetic acid:ethanol and staining by the Feulgen method. The statistical analyses were carried out using the STATGRAPHICS 6.0 computer program.

\section{Results}

The purpose of the present work was to determine if the genes controlling rye $\mathrm{B}$ transmission rate in the $\mathrm{L}$ and $\mathrm{H}$ lines are located on the $\mathrm{A}$ or on the $\mathrm{B}$ chromosomes. If such genes were on the Bs, the progenies would show low $B$ transmission rates in plots 1 and 4, and high $B$ transmission rates in plots 2 and 3 because the status of the parental Bs is L or $\mathrm{H}$, respectively. However, if the genes were on the As, the progenies would show the same type of transmission in plots 3 and 4 because both are HL hybrids, whereas they would be of L type in plot 1, and of $\mathrm{H}$ type in plot 2.

Table 1 shows the $\mathrm{B}$ transmission obtained in plots $1-4$. These results are in agreement with the hypothesis that the genes controlling rye B transmis-

\section{Plot 2}

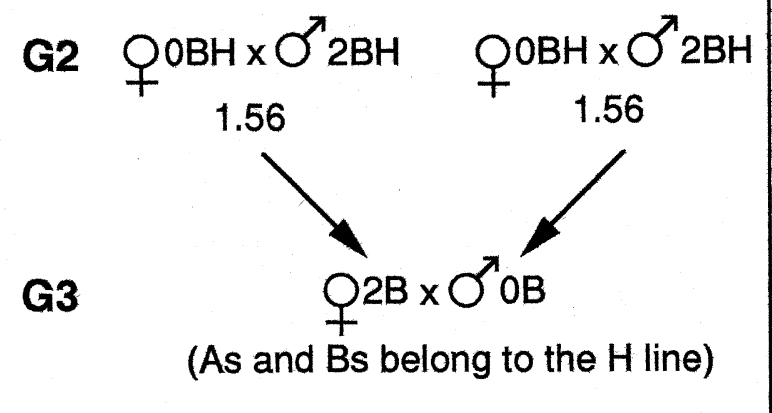

\section{Plot 4}

G2

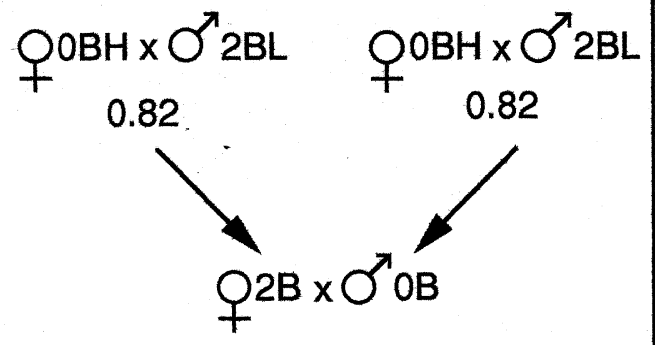

(Bs belong to the $L$ line, As are $H L$ hybrids) 
Table 1 Progeny obtained in female $2 \mathrm{~B} \times$ male $0 \mathrm{~B}$ crosses involving rye plants of the high and low $\mathrm{B}$ transmission rate lines

\begin{tabular}{|c|c|c|c|c|c|c|c|}
\hline \multirow[b]{2}{*}{ Parents of the crosses in $\mathrm{G} 2$} & \multirow{2}{*}{$\begin{array}{l}\text { No. of } \\
\text { crosses } \\
\text { in G3 }\end{array}$} & \multicolumn{4}{|c|}{$\mathrm{B}$ frequency in the progeny } & \multirow{2}{*}{$\begin{array}{l}\text { Total } \\
\text { no of } \\
\text { plants }\end{array}$} & \multirow{2}{*}{$\begin{array}{c}\text { Mean } \\
\text { no of Bs } \\
\text { per plant }\end{array}$} \\
\hline & & 0 & 1 & 2 & 4 & & \\
\hline Female $0 \mathrm{~B} \mathrm{~L} \times$ male $2 \mathrm{~B} \mathrm{~L}($ plot 1$)$ & 6 & 85 & & 53 & 4 & 142 & 0.86 \\
\hline Female $0 \mathrm{~B} \mathrm{H} \times$ male $2 \mathrm{~B} \mathrm{H}($ plot 2$)$ & 5 & 39 & 2 & 67 & 3 & 111 & 1.33 \\
\hline Female $0 \mathrm{~B} \mathrm{~L} \times$ male $2 \mathrm{~B} \mathrm{H}($ plot 3$)$ & 6 & 53 & 3 & 94 & & 150 & 1.27 \\
\hline Female $0 \mathrm{~B} \mathrm{H} \times$ male $2 \mathrm{~B}$ L $($ plot 4$)$ & 6 & 173 & 3 & 43 & & 219 & 0.41 \\
\hline
\end{tabular}

sion rate are located on the Bs because the progenies of plots 1 and 4 have a low mean Bs per plant (0.86 and 0.41 , respectively) like their $\mathrm{L} 2 \mathrm{~B}$ parents (Fig. 1), whereas the progenies of plots 2 and 3 show high mean frequencies of Bs per plant (1.33 and 1.27, respectively) like their $\mathrm{H} 2 \mathrm{~B}$ parents (Fig. 1).

This conclusion is further supported by the following analysis. The mean number of Bs per plant in the 23 crosses summarized in Table 1 was compared by a two-way ANOva (Table 2). The sources of variation were ' $0 \mathrm{~B}$ female parent' and ' $2 \mathrm{~B}$ male parent' because we compare the progeny of the $0 \mathrm{~B}$ female parent, which transmits only the As in G2, and the male parent which transmits the As and the Bs in G2 (Fig. 1). If the genes controlling B transmission rate were on the As, we should find significant differences for both sources of variation, because the $\mathrm{H}$ or $\mathrm{L}$ genes of the As would be transmitted by both the $0 \mathrm{~B}$ and $2 \mathrm{~B}$ parent plants, whereas if the genes were on the Bs we should find significant differences only for the male parent, because this is the only source of $\mathrm{H}$ or L Bs in G2. The results of the ANOVA show that the effect of the $0 \mathrm{~B}$ female parent is nonsignificant, whereas the effect of the $2 \mathrm{~B}$ male parent is highly significant. The interaction between the sources of variation is also significant indicating that the source of the B chromosomes is not the only factor regulating their transmission rate.

\section{Discussion}

The results of this paper unambiguously show that the main difference between the high and low B transmission rate lines selected from the Puyo population is caused by 'genes' located on the Bs. The significant interaction between the main effects of the ANOva (Table 2) suggests that the A chromosomes also affect transmission, but to a relatively small extent.

We have reported in previous papers that the low or high $\mathrm{B}$ transmission rate in crosses involving $2 \mathrm{~B}$ and $0 \mathrm{~B}$ plants is caused by the differential proportion of $0 \mathrm{~B}$ vs. $2 \mathrm{~B}$ gametes produced by the $2 \mathrm{~B}$ plant and not by a different nondisjunction rate. On the other hand, the proportion of $0 \mathrm{~B}$ and $2 \mathrm{~B}$ pollen grains formed by a $2 \mathrm{~B}$ plant depends mainly on $\mathrm{B}$ univalent or bivalent formation at metaphase I (Jiménez et al., 1995, 1997). According to these data, the simplest assumption is that the 'genes' for high or low transmission rate selected in the $\mathrm{H}$ and $\mathrm{L}$ lines are sites for chiasma formation located on the B chromosomes.

Table 2 Analysis of variance for the mean number of Bs in the progeny of plots $1-4$

\begin{tabular}{lcccrr}
\hline Source of variation & SS & d.f. & MS & $F$ & $P$ \\
\hline Main effects & & & & & \\
$\quad$ A: 2B male parent & 2.800 & 1 & 2.800 & 34.038 & $<0.0001$ \\
$\quad$ B: 0B female parent & 0.272 & 1 & 0.272 & 3.311 & 0.0846 \\
Interactions & & & & & \\
$\quad$ AB & 0.432 & 1 & 0.432 & 5.253 & 0.0335 \\
Residual & 1.562 & 19 & 0.082 & & \\
Total (corrected) & 5.093 & 22 & & & \\
\hline
\end{tabular}


The $\mathrm{B}$ transmission rate did not increase in the $\mathrm{H}$ line, or decrease in the L line, from the first to the second and third generations of the selection process, indicating a high heritability and a low number of loci controlling the selected character, probably just one. It should be noted, however, that the selection method $(2 \mathrm{~B} \times 0 \mathrm{~B}$ crosses $)$ does not permit the selection of the extremes of the distribution because the lowest end consists of all $0 \mathrm{~B}$ progenies and the highest contains nearly all $\mathrm{B}$ carriers. We must select $\mathrm{L}$ progenies with some $2 \mathrm{~B}$ plants because $0 \mathrm{~B} \times 0 \mathrm{~B}$ crosses lack any information about $\mathrm{B}$ transmission. We selected $\mathrm{H}$ progenies with some $0 \mathrm{~B}$ plants so that a similar selection process was used in both lines and because $2 \mathrm{~B} \times 2 \mathrm{~B}$ crosses produce many $4 \mathrm{~B}$ offspring which are difficult to maintain because of their low fertility.

Besides rye, there are a number of species where variation in B transmission rate has been reported: Zea mays (Carlson, 1969; Rosato et al., 1996), Hypochoeris maculata (Parker et al., 1982), Myrmeleotettix maculatus (Shaw \& Hewitt, 1985; Shaw et al., 1985), Pseudococcus affinis (Nur \& Brett, 1985, 1987, 1988), Crepis capillaris (Parker et al., 1989), Locusta migratoria (Viseras et al., 1990) Nasonia vitripennis (Beukeboom \& Werren, 1993) Aegilops speltoides (Cebriá et al., 1994), Allium schoenoprasum (Bougourd \& Plowman, 1996) and Eyprepocnemis plorans (Herrera et al., 1996). The finding that the genes controlling rye $\mathrm{B}$ transmission rate are located on the $\mathrm{Bs}$ is unexpected because most previous reports, including our own (Puertas et al., 1993), demonstrate or assume that transmission rate modifier genes are located on the As. But few studies unambiguously locate transmission rate modifier genes and the existence of genes located on the Bs is usually untested. For example, Nur \& Brett (1987) compared males carrying the same B and the same paternal genome but differing in their maternal genome; they demonstrated the existence of transmission rate modifier genes on the As, but possible variation in the Bs was not tested.

The results of the present paper give us a new view of the genetic mechanisms which maintain rye $\mathrm{Bs}$ in populations. If the genes controlling B transmission rate are located on the Bs we could think of the Bs controlling and moderating their own presence in rye populations.

The mechanism of rye $\mathrm{B}$ accumulation is remarkably strong and rye is the only species where the 'drive' has been shown to occur on both the female and male sides. Moreover, in all studied rye populations, B-directed nondisjuntion occurs in nearly 100 per cent of the pollen grains having the B (Romera et al., 1989). This strong drive is thought to be counteracted by the harmful effect of a high number of Bs on the fitness of the carrier. In addition, it might also be counteracted by the tendency of the Bs of the L-type to be lost because L 2B plants produce many $0 \mathrm{~B}$ gametes. L-type carriers would be favoured by natural selection because they would suffer less from the B's deleterious effects. However, this apparent benefit may be counteracted by another harmful effect, because L 2B plants produce a high percentage of inviable pollen grains compared to the H 2B ones (Jiménez et al., 1977).

Considering that the $\mathrm{L}$ and $\mathrm{H}$ Bs may be at different frequencies in different populations and that the carriers may have different fitnesses, it would be possible to maintain stable polymorphisms when the drive/loss balance is reached. Conversely, it might be possible for one type of $\mathrm{B}$ to be replaced by the other. According to Camacho et al. (1996) new selfish variants can appear from time to time replacing the former $\mathrm{B}$ version because of their superior transmission performance. It is also possible that there are different explanations for every species, either because the Bs have different evolutionary behaviour in different species or because the extant Bs are at different stages of the evolutionary process in each species or population.

\section{Acknow ledgements}

This work was supported by the grant PB 95-0133 of the DGES (MEC) of Spain.

\section{References}

BEUKEBOOM, L. W. 1994. Bewildering Bs: an impression of the 1st B-chromosome conference. Heredity, 73, $328-336$.

BEUKEBOOM, L. W. AND WERREN, J. H. 1993. Transmission and expression of the parasitic paternal sex ratio (PSR) chromosome. Heredity, 70, 437-443.

BOUgourd, s. M. AND Plowman, A. B. 1996. The inheritance of B chromosomes in Allium schoenoprasum L. Chromosome Res., 4, 151-158.

CAMACHO, J. P. M., CABRERO, J., LÓPEZ-LEÓN, M. D. AND SHAw, M. W. 1996. Evolution of a near-neutral B chromosome. In: Henriques-Gil, N., Parker, J. S. and Puertas, M. J. (eds) Chromosomes Today, vol. 12, pp. 301-318. Chapman and Hall, London.

CARLSON, w. 1969. Factors affecting preferential fertilisation in maize. Genetics, 62, 543-554.

CEBriá, A., NAVARro, M. L. AND PUERTAS, M. J. 1994. Genetic control of B chromosome transmission in Aegilops speltoides (Poaceae). Am. J. Bot., 81, 1502-1507.

HERRERA, J. A., LÓPEZ-LEÓN, M. D., CABRERO, J., SHAW, M. W. AND CAMACHO, J. P. M. 1996. Evidence for chromo- 
some drive suppression in the grasshopper Eyprepocnemis plorans. Heredity, 76, 633-639.

JIMÉNEZ, M. M., ROMERA, F., GALLEGO, A. AND PUERTAS, M. J. 1995. Genetic control of the rate of transmission of rye $\mathrm{B}$ chromosomes. II. $0 \mathrm{~B} \times 2 \mathrm{~B}$ crosses. Heredity, 74, 518-523.

JIMÉNEZ, M. M., ROMERA, F., GONZÁLEZ-SÁNCHEZ, M. AND PUERTAS, M. J. 1997. Genetic control of the rate of transmission of rye B chromosomes. III. Male meiosis and gametogenesis. Heredity, 78, 636-644.

JONES, R. N. 1995. Tansley review no. 85. B chromosomes in plants. New. Phytol., 131, 411-434.

JONES, R. N. AND PUERTAS, M. J. 1993. The B chromosomes of rye (Secale cereale L.). In: Dhir, K. K. and Sareen, T. S. (eds) Frontiers in Plant Science Research, pp. 81-112. Bhagwati Enterprises, Delhi.

NUR, U. AND BRETT, B. L. H. 1985. Genotypes suppressing meiotic drive of a B chromosome in the mealybug Pseudococcus obscurus. Genetics, 110, 73-92.

NUR, U. AND BRETT, B. L. H. 1987. Control of meiotic drive of B chromosomes in the maelybug Pseudococcus affinis (obscurus). Genetics, 115, 499-510.

NUR, U. AND BRETT, B. L. H. 1988. Genotypes affecting the condensation and transmission of heterochromatic B chromosomes in the mealybug Pseudococcus affinis. Chromosoma, 96, 205-212.

PARKER, J. S., TAYLOR, S. AND AINSWORTH, C. C. 1982. The B-chromosome system of Hypochoeris maculata. III. Variation in B-chromosome transmission rates. Chromosoma, 85, 299-310.

PARKER, J. S., JONES, G. H., EDGAR, L. AND WHITEHOUSE, C. 1989. The population cytogenetics of Crepis capillaris. II. The stability and inheritance of B-chromosomes.
Heredity, 63, 19-27.

PUERTAS, M. J., JIMÉNEZ, M. M., ROMERA, F., VEGA, J. M. AND DíEZ, M. 1990. Maternal imprinting effect on B chromosome transmission in rye. Heredity, 64, 197-204.

PUERTAS, M. J., JIMÉNEZ, M. M. AND ROMERA, F. 1993. Rye $\mathrm{B}$ chromosome transmission depends on the $\mathrm{B}$, the carrier of the $\mathrm{B}$ and the mother of the carrier. In: Sumner, A. T. and Chandley, A. C. (eds) Chromosomes Today, vol. 11, pp. 391-399. Chapman and Hall London.

ROMERA, F., VEGA, J. M., DíEZ, M. AND PUERTAS, M. J. 1989. B chromosome polymorphism in Korean rye populations. Heredity, 62, 117-121.

ROMERA, F., JIMÉNEZ, M. M. AND PUERTAS, M. J. 1991. Genetic control of the rate of transmission of rye $\mathrm{B}$ chromosomes. I. Effects in $2 \mathrm{~B} \times 0 \mathrm{~B}$ crosses. Heredity, 66, 61-65.

ROSATO, M., CHIAVARINO, A. M., NARANJO, C. A., PUERTAS, M. J. AND POGGIO, L. 1996. Genetic control of B chromosome transmission rate in Zea mays ssp. mays (Poaceae). Am. J. Bot., 83, 1107-1112.

SHAW, M. W. AND HEWITT, G. M. 1985. The genetic control of meiotic drive acting on the B-chromosome of Myrmeleotettix maculatus. (Orthoptera: Acrididae). Heredity, 54, 187-194.

SHAw, M. W., HEWITT, G. M. AND ANDERSON, D. A. 1985. Polymorphism in the rates of meiotic drive acting on the B-chromosome of Myrmeleotettix maculatus. Heredity, 55, 61-68.

VISERAS, E., PARDO, M. C. AND CAMACHO, J. P. M. 1990. Analysis of B chromosome transmission through females of Locusta migratoria. Bull. Genet. Soc. Can., 21s, 28. 